\title{
Physiotherapy Services in The Efforts of Health Services In DKI Jakarta Public Health Center
}

\author{
Putri Karina Syafitri, Vetty Yulianty Permanasari \\ Faculty of Public Health University of Indonesia \\ E-mail: pkarinas58@gmail.com
}

\author{
Article history \\ Posted, Jan 9th, 2020 \\ Reviewed, Feb 25th, 2020 \\ Received, March 10th, 2020
}

\begin{abstract}
The increase in non-communicable diseases such as hypertension, stroke, diabetes mellitus, joint disease, lack of physical activity, injury, and disability in line with the increasing need for physiotherapy services in health facilities, including in Public Health Centers. The role of the physiotherapist in the Public Health Centers is to carry out activities in the form of promotive and preventive without prejudice to curative and rehabilitative. The purpose of this study is to analyze physiotherapy services at the Public Health Centers using five levels of prevention measures, namely are health promotion, specific protection, early diagnosis and prompt treatment, disability limitation, and rehabilitation efforts at 6 PHC in DKI Jakarta. This study uses qualitative research methods through a phenomenological approach. The results of this study obtained a depth-overview of the efforts of health services that the provision of medical services is preferred over promotive and preventive efforts. Physiotherapy services at the PHC have been regulated in the Decree of the PHC's Head by referring to Permenkes 75 (2014). Public health activities in collaboration with the Physiotherapy Services are only carried out by 3 PHC, and some of them only conduct individual services. This study recommends that adding one physiotherapist to be able to help physiotherapy services outside the building PHC and physiotherapy organizations can create public health training to support physiotherapy competencies.
\end{abstract}

Keywords: public health centers; physiotherapy services; five levels of prevention

\begin{abstract}
ABSTRAK
Meningkatnya penyakit tidak menular seperti hipertensi, stroke, diabetes melitus, penyakit sendi, aktivitas fisik kurang, cedera, dan disabilitas sejalan dengan peningkatan kebutuhan masyarakat akan layanan fisioterapi di sarana kesehatan termasuk Puskesmas. Peran dan fungsi Fisioterapis di Puskesmas yaitu melakukan kegiatan berupa promotif dan preventif tanpa mengesampingkan kuratif dan rehabilitatif. Tujuan dari penelitian ini yaitu menganalisis layanan fisioterapi di Puskesmas menggunakan lima tingkatan upaya preventif yaitu health promotion, spesific protection, early diagnosis and prompt treatment, disability limitation dan rehabilitation di enam Puskesmas wilayah DKI Jakarta. Penelitian ini menggunakan metode penelitian kualitatif melalui pendekatan fenomenologi. Hasil dari penelitian ini didapatkan
\end{abstract}


gambaran mendalam mengenai upaya pelayanan kesehatan pada layanan fisioterapi di Puskesmas yaitu pemberian pelayanan pengobatan lebih diutamakan dibandingkan upaya promotif dan preventif. Pelayanan fisioterapi di Puskesmas sudah diatur dalam SK Kepala Puskesmas dengan mengacu pada Permenkes No. 75 tahun 2014. Kegiatan kesehatan masyarakat yang bekerjasama dengan layanan fisioterapi di Puskesmas hanya dilakukan oleh 3 Puskesmas dan sebagiannya hanya melakukan pelayanan perseorangan saja. Penelitian ini merekomendasikan agar menambahkan satu SDM fisioterapis di Puskesmas agar dapat membantu pelayanan fisioterapi di luar gedung dan organisasi fisioterapi dapat membuat pelatihan khusus kesehatan masyarakat untuk mendukung kompetensi fisioterapi.

Kata kunci: puskesmas; layanan fisioterapi; lima upaya preventif.

\section{INTRODUCTION}

Puskesmas is the primary health facility, which is the spearhead of the delivery of basic health services at the community level (Permenkes, 2014). Based on Riskesdas in 2018, there was an increase in non-communicable diseases such as hypertension, joint disease, stroke, diabetes mellitus, lack of physical activity, injury, and disability. The highest increase in noncommunicable diseases was found in people aged over 65 years, such as hypertension, from $25.8 \%$ increased to $34.1 \%$ and stroke from 7 per mile to 10.9 per mile. Not only attacking the elderly population, diabetes mellitus in the community over the age of 15 increased from $6.9 \%$ to $8.5 \%$. There was an increase in the prevalence of the joint disease in populations over the age of 15 years by $7.3 \%$, but this was also supported by the rise in less physical activity in the population aged over ten years from $26.1 \%$ to $33.5 \%$. Besides injuries that interfere with daily activities have increased from
$8.2 \%$ to $9.2 \%$ and for the average disability in children aged 5-17 years increased by $3.4 \%$ and adults aged 18 - 59 years increased to $23.08 \%$ (Kementrian kesehatan RI, 2018).

The existence of physiotherapy services at the Public Health Centers is an effort to renew in supporting public and individual health efforts, as well as agents of change so that individuals, families, and/or community groups become healthier, fitter, and more productive. By integrating physiotherapists into health workers at the Public Health Centers, it is identified that it can improve the quality of services, and the existence of physiotherapy services at the Public Health Centers has a role especially at the promotive and preventive levels as well as direct access to curative and rehabilitative services (Ontario Physiotherapy Association, 2017). The role and function of physiotherapy in Public Health Centers, according to Permenkes Number 65 of 2015, is to carry out 
activities in the form of promotive and preventive, including screening and/or early detection. Promotive efforts by physiotherapy services to improve the degree of public health in the way of maintaining and enhancing body movements and functions with the target of services are healthy people so as not to be affected by the disease. While the preventive measures carried out by physiotherapy services are prevention of movement disorders and limited functioning, the inability of individuals who have the potential to experience movement disorders and body functions due to health, socio-economic and lifestyle factors, one of which is by providing counseling, treatment, and recovery to reduce pain complaints, and carry out programs to increase body flexibility, endurance or fitness, and alignment of posture in daily activities (Permenkes RI, 2015).

Although it is known that public understanding and awareness of the importance of the role of Physiotherapy services in the community is still low (Fai'zah and Lestari, 2017), according to the results of Black, Ingman \& Janes (2016) research on the role of the Physiotherapist in the efforts to promote physiotherapist health able to provide physical activity (91.3\%), maintain healthy body weight $(73 \%)$, and stop smoking effort (51.3\%). (Black, Ingman and Janes, 2016). Based on preliminary studies, only $2 \%$ or six Public Health Centers have physiotherapy services out of a total of 340 Public Health Centers in the DKI Jakarta area. Besides that, it is known that the absence of supporting policies related to physiotherapy services at the Puskesmas causes most of the health efforts carried out by physiotherapy services only to provide individual services, namely dominant curative and rehabilitative efforts. It is not following the role and function of physiotherapy in Public Health Centers that provide promotive and preventive services in the community.

Based on the above background, the researcher raised this issue to analyze the picture of physiotherapy services at the Public Health Centers through five levels of preventive measures namely health promotion, specific protection efforts, early diagnosis and prompt treatment efforts, disability limitation efforts and rehabilitation efforts at six Public Health Centers (Puskesmas) in the DKI Jakarta area.

\section{METHOD}

This study used a descriptive qualitative research method through a phenomenological approach that aims to 
get an in-depth picture of the role of physiotherapy services in Public Health Centers (Puskesmas) in the DKI Jakarta area and accordance with the experience experienced. Data were collected from July to September 2019 in six Public Health Centers in the DKI Jakarta area that have physiotherapy services, including Matraman Sub-district Health Center, Jatinegara Sub-District Health Center, Koja Sub-District Health Center, Kebayoran Lama Sub-District Health Center, Pasar Minggu Sub-District Health Center and Pancoran Sub-District Health Center. The six Public Health Centers were selected based on the Public Health Centers in the Province of DKI Jakarta, which has Physiotherapy services.

Primary data collection was obtained from in-depth interviews obtained through sources, namely all physiotherapists in the Public Health Centers and holders programs of public health efforts in the Public Health Centers, members of the Indonesian Physiotherapy Association of DKI Jakarta and three heads of the Public Health Centers with physiotherapy services in the Public Health Centers in the DKI Jakarta area. This study has passed the ethics review through the Ethics Commission for Research and Community Service at the Faculty of Public Health, the
University of Indonesia, with ethics number 328/UN.2.F10/PPM.00.02/2019.

\section{RESULTS AND DISCUSSION}

\section{Physiotherapy Services Policy}

In every service, physiotherapy policy in the Public Health Centers refers to Permenkes Number 75 of 2014 about Public Health Centers for Public Health Efforts and Individual Health Efforts a Permenkes Number 65 of 2015 about physiotherapy service standards. Although each Public Health Centers refers to the national policy, there need for physiotherapy service standards that adapted to the conditions and needs related to the Public Health Centers. This is in accordance with the following quote:

"...kalau untuk kebijakan sendiri sih belum ada, paling yaa sesuai di permenkes 75 tahun 2015 yang UKM esensial dan pengembangan, dan memang kan ada kebijakan permenkes, pergub sampai ke interen Fisioterapi." (Informant 1)

Policies related to physiotherapy services at the Public Health Centers have been set in the Decree of the respective PHC Head. Such as in the Koja District Health Center, Kebayoran Lama District Health Center and Matraman District Community Health Center. Whereas the Standard Operational Procedures (SOP) is contained in the Decree of the Head of the PHC regarding Clinical Service Standards in each Public 
Health Centers. This is in accordance with the following quote:

"....selain itu kita ada kebijakan yaa kita punya SK kepala Puskes sendiri disini tentang pengelolaan UKM sama UKP masing-masing, yaa itu karena di SK itu kan sudah disesuaikan dengan masingmasing program tadi sesuai dengan PMK 75 lagi dan bukan dengan orang fisioterapis masuk ukm itu tapi di UKP." (Informant 2)

Based on the results of interviews with physiotherapists, program holders and PHC's heads, it was found that physiotherapy services were included in individual health services which focused on providing health services to the public with a doctor's referral because in the current health insurance era physiotherapy services are still included in specialist services in primary health services. (Yuniarti and Lingga, 2019) Therefore the support from the Public Health Centers policy also makes physiotherapy services focus on providing treatment services with curative efforts in primary health services but not to promotive and preventive health services. In addition to being involved with public health, efforts depend on the authority and policies of the program holders because there are no restrictions and regulations that govern what workers can and cannot be involved with the program in public health efforts.
Although there has been a national policy, namely Permenkes Number 65 of 2015 concerning Physiotherapy Service Standards, the role of the Internal Physiotherapy Policy has not been able to meet the qualifications of the entry of physiotherapists to engage in activities in public health efforts. Because most program holders and Puskesmas leaders assume that physiotherapy services are services or services to provide healing and recovery to individuals that are curative and rehabilitative, at the same time, for counseling and prevention to the community cannot be done by physiotherapists at Public Health Centers. Physiotherapists, according to Maharaj, Chung, \& Cott (2018), as a health professional, can provide exercise movements and recipes for physical activity to the community and can significantly contribute to reducing the burden of morbidity and mortality in noncommunicable diseases. (Maharaj et al., 2018)

\section{Human Resources of Physiotherapy}

The availability of Physiotherapist HR in Public Health Centers in the DKI Jakarta area is still very lacking, and there are only seven physiotherapists implementing personnel spread in six District Public Health Centers out of 44 Public Health Centers Centers in the DKI Jakarta area. 
The limitations of the physiotherapist in the PHC were not the inclusion of physiotherapy in nine minimum health workers in the Public District Health Centers. Therefore the physiotherapist is not evenly distributed in every DKI Jakarta Public Health Centers. This is in accordance with the following quote:

"karena kan cuma 1 yaa dia ga bisa kemana-kemana di pelayanan aja kalau fisio karena kan tupoksi nya di ukp." (Informant 2)

The Physiotherapist's HR only carries out activities in the building or treatment as well as carrying out its primary duties and functions beyond the provision as physiotherapy services. Like the physiotherapist in the district health center Kebayoran Lama responsible for medical devices ranging from planning, reporting actions to the distribution of medical devices. Another thing with the district health center of Jatinegara physiotherapist performs his duties as well as the person in charge of Office Stationery in the Puskesmas area. Likewise, with the physiotherapist district health center of Pasar Minggu, which performs tasks in the quality section as a control document, customer service, internal audit. Besides, physiotherapists in the district health center of Koja conduct other activities such as Hajj input, medical record audits, and quality indicator audits. “...ada, saya di bagian mutu sebagai dokumen control, pelayanan pelanggan, audit internal, jadi mau gamau ada temen saya jadi bendahara barang. Iyaa ikut juga. program ptm, haji, lansia." (Informant 3)

Based on interviews with sources, the existence of other duties outside of their primary responsibilities as physiotherapists can indeed support the abilities of individuals but not in their duties as health workers in the Puskesmas. The role of physiotherapist human resources who work at the Public Health Centers is mostly to carry out individual healing actions with the physiotherapy tools approach based on a referral from a doctor. However, it was found that three out of Public Health Centers in physiotherapy services, in addition to providing individual health measures, were also involved in community health service efforts.

The main task and function of the physiotherapy service at the Public Health Centers is to carry out the main physiotherapy actions in providing health services in a promotive and preventive manner without compromising curative and rehabilitative efforts. In providing curative services, physiotherapists are authorized to conduct physiotherapy examination history, make medical records, and provide counseling that can be promotive and 
preventive in the Public Health Centers building.

“....buat laporan pmkp jadi apa namanya anggota tapi kalo missal kan kayak aku disini ada UBM aku bantuin mereka turun lapangan untuk UBM, penyuluhan tapi materinya tentang UBM ngasih edukasi dan kuisioner tentang upaya berhenti merokok." (Informant 4)

The physiotherapist's function in the Puskesmas in promotive and preventive efforts was seen from the District Health Center of Matraman is involved in quitting smoking service. In contrast, the District Health Center of Jatinegara is involved in the Health Efforts of Schools, and the District Health Center of Pasar Minggu was involved in the Hajj health service, NCD's health service, and Elderly health service. However, this physiotherapist role is felt to be inadequate because of the uneven distribution of human health resources in Public Health Centers in Indonesia especially in DKI Jakarta (Mujiati and Yuniar, 2017).

In addition to conducting clinical services at the Public Health Centers, the physiotherapist has also given a task to perform other duties inside the building. But over the many responsibilities of nonclinical makes the lack of activities that can be carried out by a physiotherapist outside the building or in the community.
According to Halimuddin's research (2015), if the employee carries out additional duties outside of their main task and function tends to be less effective so that it will affect the performance of the employee.

\section{Physiotherapy Competencies}

Based on Permenkes Number 80 of 2013 about Physiotherapy Practice Standards, as physiotherapists who work at the Community Health Centers must have at least a Registration Certificate (STR), a Physiotherapy Practice License (SIPF) and a minimum of D3 Physiotherapy education (Permenkes RI, 2013). This has been fulfilled by all physiotherapists who work at the Jakarta Public Health Center. To support promotive and preventive services at the Public Health Centers, physiotherapists need to have ineffective competence communication, one of which is by attending training as a health promoter. However, such training rarely involves physiotherapists at the Public Health Centers. This is in accordance with the following quote:

"STR dan SIPF wajib punya kalau di puskes yaa.. dan ini karna tidak terjadi juga ada pelatihan untuk melibatkan fisioterapi di program ukm, kalopun ada fisio harus bisa promkes." (Informant 5)

"jadi kalo program ukm tadi bagaimana kita mencegah, intinya mencegah, promosi tidak rehabilitasi, bagaimana memberikan promosi, komunikasi yang baik, ke masyarakat. Kalo orang yang ke puskesmas 
kita mengharapkan orang-orang yg sehat juga datang." (Informant 6)

Based on the results of interviews with physiotherapists and program holders of public health efforts, there has been no specific training for physiotherapists. Still, it is required for all health workers at the PHC to be able to carry out health promotion activities ranging from counseling, prevention, and communicating with the community in the Public Health Centers' working area. In contrast to services in hospitals, physiotherapists in Puskesmas are required to be able to provide counseling and collaborate in carrying out activities that are promotive and preventive. To be able to do health education, physiotherapists must have the ability and competence to provide efforts such as Health Promotion (Abaraogu, Edeonuh, and Frantz, 2016). Training and competency development are needed to improve the ability of the physiotherapist in creating a public health service activity in collaboration with other health workers in the program at the PHC. According to physiotherapists on duty at the Public Health Centers is need specialized training to promote health and prevent disease with wider coverage. The skills owned by health workers in the Puskesmas can affect the training they get (Putri, 2018).

\section{Health Promotion}

In addition to making treatment efforts, physiotherapists at the Public Health Centers can have a role in promoting health inside and outside the building. In undertaking health promotion efforts at the Public Health Centers, physiotherapists make plans for physiotherapy service activities by collaborating with programs in the PHC. This is in accordance with the following quote:

“....yaaa fisioterapis harus jadi promotor terutama mereka harus menguasai dan juga harus sebagai promosi kesehatan, mereka juga harus bisa edukasi ke masyarakat, karna kita rencana nya mau ngajak mereka untuk lebih ke arah promosi dan peragaan kesehatan ke anak-anak sekolah." (Informant 1)

Based on the results of the interviews obtained physiotherapy services in the Public health center in Jatiegara Distric is carries out health promotion in the school environment in collaboration with holder program school health effort to provide counseling in the form of demonstration of how to sit well, provide education for children to carry out physical activities that are appropriate for a reasonable and measured age level and also provided education in the treatment of acute injuries. This is based on the following quote:

“....waktu itu saya ngajuin buat kerjasama, nah disitu kesempatan saya untuk jabarin 
lah kompetensi yang dimiliki fisio, dan jelasin kita bisa apa, yaa minimal komunikasi dulu sih ke pemegang program ukm nya, baru mereka yang nentuin kita bisa dimana nih. Kebetulan memang peluangnya disini buat fisio sih di anakanak sekolah jadi ikutlah sama program UKS nya." (Informant 7)

In hajj health services, physiotherapist in Pasar Minggu Public Distric Health Centers collaborates with program holder in hajj health to provide health education in the form of balance screening, physical exercise and safe exercise to maintain the fitness of prospective pilgrims. Based on the results of interviews with physiotherapists and program holders in public health efforts on the Hajj Health Services at the Pasar Minggu PHC, physiotherapist play a major role in providing fitness education and controlling the elderly pilgrims who do not experience movement and bodily functions impaired during worship. In line with Wahyuni's research (2006) that Physiotherapy services have an important role in physical fitness and fitness because it is known that $70 \%$ of hajj activities are physical activities (Wahyuni, 2006). According to research (Ningsih, 2005) by providing Hajj exercises can affect the increased endurance of the pulmonary heart, which is done on prospective pilgrims who are not at high risk. (Ningsih, 2005).
Based on interviews with physiotherapists and program holders at the PHC of Matraman district, a physiotherapy service contributes with the holder of the Stop Smoking Efforts or (UBM) program to conduct health education. The involvement of physiotherapists in the UBM program is expected so that people who try to stop smoking can restore their fitness and lung health. But additional training is still needed on the physiotherapist to provide intervention to patients and clients in delivering doses for physical activities to promote and support efforts to stop smoking (Bezner, 2015). But it is different from physiotherapy services in the PHC of Koja district in providing health promotion efforts to the public through with the print media that is making leaflets or commonly called sheets of paper containing writings on physiotherapy services and the benefits of physiotherapy in the form of pictures of active exercise movements with short sentences, filled with pictures that are simple and easy to understand (Haryani, Sahar and Sukihananto, 2016). Health promotion media is a tool used to deliver material about health to the community by considering the objectives of health promotion (Notoatmodjo, 2015). In line with the role of the physiotherapist in health promotion efforts by most people based on their perception that the physiotherapist can provide health 
promotion to the community as a role model for regular physical activity $(83.4 \%)$, maintaining a healthy body weight (71.7\%), and actions to stop smoking by (63.9\%) (Black, Ingman and Janes, 2016).

\section{Specific Protection}

In carrying out of specific protection efforts, physiotherapy services also collaborate with programs holder in a public health effort to make specific prevention efforts so that people are not affected by the disease, even those already affected by the disease can also be given specific protection without using or taking drugs. Physiotherapy services do this at Pasar Minggu Public Health Centers by collaborating on the elderly program and non-communicable disease (PTM) services by providing regular exercise every month and doing it every week. This is in accordance with the following quote:

"yaa kalo promotif kan promosiin fisioterapi, nah kalo preventif untuk tahap ini sih hampir sama, paling untuk lansia, DM kita ada senam prolanis, senam DM rutin tiap bulan." (Informant 7)

Based on the results of interviews with physiotherapists who work at the Jakarta Health Center for patients with indications of respiration, cases will be given inhalation therapy. The device is used with a nebulizer mask on a patient that is one person, and one mask is not allowed to use masks that have been used by others. In addition to the use of inhalation masks, physiotherapists also carry out special protections at the Service by using PPE (Personal Protective Equipment) and also use surgical masks. This is in accordance with the following quote:

"untuk di Poli kita kadang suka pake APD dan hand scoon, trus sama masker buat nebu satu orang satu, sama kalo pasien beresiko paling kita kasih masker wajah." (Informant 8)

According to Permenkes Number 27 of 2017, providing knowledge to health workers on how to store, dispose of, handle, and reuse medical equipment safely is important to prevent the occurrence of infectious diseases. Physiotherapy services at the Puskesmas are also given education and training related to specific protection to reduce the risk of falling in the elderly, mainly by providing prolanis exercises, as well as fitness exercises, which are in line with Supriyono's research (Supriyono, 2015) and also in people with diabetes to increase physical activity and reduce sugar levels in the body (Colberg et al., 2016) that is given diabetes exercises every week at the Public Health Center.

\section{Early Diagnosis and Prompt Treatment}

To early diagnosis and prompt treatment, physiotherapy services perform their role to 
prevent the occurrence of disabilities and complications in patients and the community. Physiotherapy services perform this role as a first step to determine the treatment program that will be provided by physiotherapists at the Public Health Centers. The role of the Physiotherapist in managing early diagnosis and prompt treatment is to do re-examine the doctor's referral patient to determine the appropriate treatment and usually given for 2-3 visits to be able to see the lack of complaints of patients who come physiotherapy services. If recognized and rechecked, there is no reduction in complaints to the patient, and it will be discussed again with the doctor and given a patient evaluation, this is in accordance with the following quote:

“....kalo kita sih di pelayanan ada SOAP, untuk anamnesa pasien diasesmen lagi keluhan nya apa untuk tau posisi persisnya, juga tanya dia pekerjaan nya apa karna nanti ngaruh ke gerakan dia, trus paling kita evaluasi karna kita juga kan udah pake epus ya diliat dari kedatangannya aja sih bisa." (Informant 9)

Based on the results of interviews with physiotherapists and program holders at the PHC, physiotherapy services for conducting screening activities must work together with program holders at the Public Health Centers. Physiotherapy services in PHC of Pasar Minggu district have conducted a balance check with the screening test and have taken fitness measurements on the Prospective Hajj
Pilgrimage in collaboration with the Hajj health service and also Sports Health service. By screening fitness for prospective pilgrims with certain methods such as Rockport to measure heart and lung fitness, this is in line with Budiman et al. research (2017). (Budiman, Aprijana, and Iskandar, 2017). Meanwhile, in individual health services, physiotherapy services that only provide care in the building are integrated with personal health services in accordance with policies at the Public Health Centers. Physiotherapy has a special role in preventing the occurrence of movement and function disorders that cause prolonged disability (Frantz and Ngambare, 2013).

\section{Disability Limitation}

Based on its role in managing preventive efforts on disability limitations, physiotherapy services at the Puskesmas make their efforts by providing care so that patients who have already been treated do not have disabilities or body movement and function limitations. At the physiotherapy service at the PHC, efforts to disability limitations are made to patients from general health service referrals by providing physiotherapy modalities to avoid complications and movement disorders. Besides being done in physiotherapy services, efforts to disability limitations are also given for training at 
home. these efforts are given to reduce the pain condition, and patient complaints to remain active in their activities and do not arise disabilities.

"....yaa itu pasti kita asesmen dulu diawal kalo kita tau keterbatasan nya dulu kemampuannya sampe mana kalo misalnya ternyata harus ditindak lebih lanjut dan area nya yg luas kita harus merujuk ke rumah sakit gitu, tapi kalo selama masih bisa kita handle dengan area dan alat yang ada disini kita lakukan disini." (Informant 10)

To disability limitation, physiotherapy services play a role in overcoming the problem of the range of motion of joints that began to be limited, reduce complaints by using physiotherapy intervention methods, and also supported by physiotherapy modalities at the Public Health Centers (Permenkes RI, 2015). Based on the results of interviews with physiotherapists on duty at the PHC, the average patient who came to the physiotherapy services is a patient referral, and to evaluate the absence or disability or other complaints, physiotherapist always records every action in the medical record and also communicates it with the doctor.

\section{Rehabilitation}

Rehabilitation efforts referred to this study are rehabilitation in the scope of prevention in physiotherapy services in the DKI Jakarta Public Health Center so that patients are not getting worse and are expected to return to their original activities. This rehabilitation effort is carried out to prevent people who have experienced complaints from being exposed to recurring risks. This is following the following quote:

"upaya rehabilitasi ini kalo di Puskesmas upaya pencegahan ya supaya pasien tidak jatuh pada saat jalan misalnya, kayak lansia kalo kita latih untuk mencegah agar tidak jatuh dan kena penyakit yang berulang." (Informant 11)

In its role in individual health services, physiotherapy services at the PHC collaborate with doctors in general poly and nurses. If there are indications with other complaints of movement and bodily functions are also communicated again with the sending doctor. It can be recommended to other poly by the complaint. To develop physiotherapy services as rehabilitation services at the PHC, physiotherapists can perform their role in providing input to the PHC's leaders, so that physiotherapy services can be maximized to provide services to the community at the PHC. The physiotherapist can advise during an internal meeting to add physiotherapy modalities. This is following the following quote:

"kemarin paling saya minta tambahan alat-alat aja buat ngebantu di pelayanan." (Informant 4) 
Based on the results of the interview, it is hoped that it can improve physiotherapy services and also reduce referrals to advanced health facilities due to the limitations of equipment and treatment rooms in physiotherapy services at the Public health centers in the DKI Jakarta. At the rehabilitation level, physiotherapy services develop counseling and follow-up efforts that must be carried out by people who are in health recovery so that they can also be done at home. Namely providing education for the community or clients about living with mobility aids, also involving families in every treatment for the community, and helping to restore the client's confidence so that he can return to his activities in the community optimally. This can simultaneously reduce the level of disability, hospitalization, and health care costs (Gustavson et al., 2017).

\section{CONCLUSION}

From the efforts of health services that have been carried out in physiotherapy services in Jakarta's Public Health Centers, it can be seen that the role of physiotherapy services based on its policy is to conduct individual health services. Efforts to provide public health services by physiotherapy services at the Public Health Centers can be carried out based on the policies and authority of program holders involving physiotherapists. However, at this time, the lack of policy support for physiotherapy services in providing public health efforts is still a matter of physiotherapists at PHC. The dominance of individual health efforts at the PHC and the limitations of physiotherapist HR at the Puskesmas reduce the role of Physiotherapy services at the Puskesmas to be able to provide public health services. It can be suggested for the DKI Jakarta Health Office to carry out monitoring and evaluation to see the problems and the development of six physiotherapy services in the Jakarta Public Health Center and also to add at least one Health Human Resources for Physiotherapist in the Health Center so that they can carry out activities outside the Public Health Center building and can evenly distribute physiotherapy services at the PHC. Also, Physiotherapy Organizations must be able to increase the advocacy ability of the organization so that physiotherapists can be better known among health institutions and the community and conduct training related to Public Health Promotion, especially in Public Health Centers.

\section{REFERENCE}

Abaraogu, U. O., Edeonuh, J. C., and Frantz, J. 2016. 'Promoting physical activity and exercise in daily practice: Current practices, barriers, and training needs of physiotherapists in eastern Nigeria', Physiotherapy Canada, 68(1), pp. 
$37-45$.

Bezner, J. R. 2015. 'Perspective Promoting Health and Wellness: Implications for Physical Therapist Practice', ptjournal.apta.org, 95(10), pp. 1433-1444.

Black, B., Ingman, M., and Janes, J. 2016. 'Promotion as Perceived by the Patient: Descriptive Survey', American Physical Therapy Association, 96(10), pp. 1588-1596.

Budiman, I., Aprijana, I. and Iskandar, D. 2017. 'Penggunaan Tes Lapangan $1,6 \mathrm{Km}$ Metoda Rockport Untuk Pengukuran Kebugaran JantungParu Dengan Baku Emas Treadmill Metoda Bruce', Jurnal Sains Keolahragaan dan Kesehatan, 2(2), pp. 38-41.

Colberg, S. R. et al. 2016. 'Physical activity/exercise and diabetes: A position statement of the American Diabetes Association', Diabetes Care, 39(11), pp. 2065-2079.

Frantz, J. M. and Ngambare, R. 2013. 'Physical Activity and Health Promotion Strategies Among Physiotherapists in Rwanda', African Health Sciences, 13(1), pp. 17-23.

Gustavson, A. M. et al. 2017. 'Public Health Impact of Frailty: Role of Physical Therapists', The Journal of frailty \&amp; aging, 6(1), pp. 2-5.

Halimuddin. 2015. 'Pengaruh Beban Kerja, Lingkungan Kerja Dan Disiplin Kerjaterhadap Kinerja Pegawai (Studi Balai Penelitian dan Pengembangan Pengendalian Penyakit Bersumber Binatang Donggala, Kementerian Kesehatan $\mathrm{RI})$, e-jurnal katalogis, 3(11), pp. 61-72.
Haryani, S., Sahar, J. and Sukihananto, S. 2016. 'Penyuluhan Kesehatan Langsung dan melalui Media Massa Berpengaruh terhadap Perawatan Hipertensi pada Usia Dewasa Di Kota Depok', Jurnal Keperawatan Indonesia, 19(3), pp. 161-168.

Hasil Utama Riset Kesehatan Dasar. 2018. Kementrian kesehatan Republik Indonesia. Badan Penelitian dan Pengembangan Kesehatan.

Maharaj, S. et al. 2018. 'Integrating physiotherapists into primary health care organizations: The physiotherapists' perspective', Physiotherapy Canada, 70(2), pp. 188-195.

Mujiati, M. and Yuniar, Y. 2017. 'Ketersediaan Sumber Daya Manusia Kesehatan pada Fasilitas Kesehatan Tingkat Pertama dalam Era Jaminan Kesehatan Nasional di Delapan Kabupaten-Kota di Indonesia', Media Penelitian dan Pengembangan Kesehatan, 26(4), pp. 201-210.

Ningsih, I. S. 2005. 'Pengaruh Latihan Senam Haji Terhadap Peningkatan Daya Tahan Jantung Paru Pada Calon Jamaah Haji Non Resiko Tinggi', 5(2), pp. 45-50.

Notoatmodjo, S. 2015. Metodologi Penelitian Kesehatan: Edisi Revisi. Jakarta: Rineka Cipta.

Ontario Physiotherapy Association. 2017. 'Physiotherapy in Primary Health Care', Physiotherapy in Primary Health Care, 1(10), pp. 1-13.

'Peraturan Menteri Kesehatan Nomor 75 tahun 2014 tentang Pusat Kesehatan Masyarakat.

Peraturan Menteri Kesehatan Republik Indonesia Nomor 80 Tahun 2013 
161 Jurnal Ilmu Teknologi Kesehatan, Vol. 7, No. 2, March 2020, pp:147-161

tentang Penyelenggaraan

Pekerjaan dan Praktik Fisioterapis.

Peraturan Menteri Kesehatan Republik Indonesia Nomor 65 Tahun 2015 tentang Standar Pelayanan Fisioterapi.

Putri, S. M. D. 2018. 'Pengaruh pelatihan orientasi keluarga sehat untuk mendukung program Indonesia sehat di kabupaten Lumajang tahun 2018', Berita Kedokteran Masyarakat, p. 4.

Supriyono, E. 2015. 'Aktivitas Fisik Keseimbangan Guna Mengurangi Resiko Jatuh Pada Lansia', Jurnal Olahraga Prestasi, 11(2), pp. 9195.

Wahyuni. 2006. 'Fisioterapi haji meningkatkan kesegaran jasmani', SUHUF, 28(01), pp. 27-38.

Yuniarti, D. and Lingga. 2019. 'Pengaruh Pelatihan dan Pengembangan Sumber Daya Manusia dalam Meningkatkan Kinerja Guru pada SMK Negeri 1 Muntok', Efektor, 6(1), pp. 98-106. 